\title{
Gold Pawning in Syariah Banking: An Economic Analysis
}

\author{
Darwis Harahap \\ IAIN Padangsidimpuan, Indonesia \\ Email:darwis05@yahoo.com
}

\begin{abstract}
Gold Pawning in Syariah Banking: An Economic Analysis. Gold Pawning practices in Syariah Banking may create speculative actions due to the volatility of gold prices in markets. The objective of this research is to conduct stress testing whether losses are experienced by the customers while having gold investements or known as berkebun emas. Stress testing is a testing method conducted based on gold farming simulations of the cumulative gold pawning data (qardh) of Indonesian Syariah Banking collected from March 2004 to May 2015. The results of stress testing on gold farming simulations conducted within 131 months show that customers gain profits only within 48 months while the rest 83 months they suffer from losses. It can be concuded that the gold pawning practices are not in accordance with maslahah (public interest) but, in the contrary, contain gharar (deceptive uncertainty). Thus, further studies are highly required to conduct in meeting the syariah.
\end{abstract}

Keywords - Rahn, Stress Testing, Maslahah

\section{INTRODUCTION}

Gold investment is an investment considered meeting the syariah. Not only does gold provide higher profits, its value tends to be stable and increases every year. However, in a certain period, it may also experience decreases. This gold transaction is considered as an investment which has already met the syariah as in the Holy Qur'an, it is stated that gold (dinar) and silver (dirham) may be used as currency. Although gold investment is considered as an investment based on syariah, in facts, it tends to be in contradiction with syariah values. A hadith, narrated by Bukhori and Nasa'I, mentions that the Prophet forbids gold exchanges to avoid riba' fadhl. In addition, other hadiths also forbid non-cash or installment gold purchases (murabahah). Gold may only be used as a currency.Due to Indonesian Syariah banks' funding products, there are two types of gold funding products, including gold pawning (rahn) and gold installment (murabahah). Gold pawning (rahn) is a gold pawning form made by customers who need cash. Meanwhile, gold installment (murabahah) is a gold purchasing method made by installments. However, not all Syariah banks have the gold funding product (rahn) such as in Bank Muamalat Indonesia Plc.

Gold pawning practices (rahn) are intended to fulfill costumers' daily needs which are urgent, yet require a simple and quick process. The gold pawning implementation procedural sources explain that Syariah banks estimate the highest value of the gold is maximally $85 \%$ to $90 \%$ and minimally $50 \%$ of the gold price. The pawning period is only within 4 months and may be extended. If the basic pawned gold payments have not been fully completed, other payments should be made as those initially made on gold pawning (rahn) and also the monthly payments (ujroh). Other expenses required to make include costs for goods' administration and insurance when funding is disbursed. Maintenance costs are calculated in every 15 days and paid on the initial payments completion, including the administration fee. The loans which can be made are ranging from Rp. 500,000 to Rp. $250,000,000$ [1].

When analyzed, the gold pawning practices may provide opportunities for speculates to gain profits. Pawning is intended to fulfill people's basic needs, yet the loan tolerance up to Rp. 250,000,000 may provide opportunities for speculative actions. In addition, the pawning period may be extended after four months while waiting for the gold price increases in the future. One illustration is that when an individual pawns his/her piece of gold and receives the loan, he/she may use it to buy another piece of gold and then he/she pawns it once again, and so forth. An individual may repetedly pawn his/her pieces of gold by only having a piece of gold as his/her capital at the beginning. He/she may sell the powned pieces of gold when the gold prices are increasing. This practice is then called a gold farming.

On the other hand, these speculative actions may harm both customers and the banks since gold price tends to fluctuate, ups and downs. For example, when the gold price increases in market, the customers will sell their gold and surely will gain profits, but when the gold price decreases, the customers will keep their gold at Syariah banks waiting for the gold price increase in market. In facts, the customers will never return their loan since the value of their pawned gold is higher than the customers' gold price. 
As explained by [2] that the gold price volatility may create problem for both customers and the bank. First, due to gold pawning phenomena which are transformed into gold investments with speculative actions, costumers in facts are having gold farming activities. Those change tabarru' (a non compensatory contract) agreement into speculative actions and deny the Syariah banks' business activities which are required to be prudent, having social motives and free from speculative actions. Second, when the gold prices are fluctuating, the excessive gold pawning activities have potentials to inhibit the prudential banking operation. It may become a problem when the customers' funding money is used by Syariah banks to finance the gold pawning. Third, when the gold prices decrease, the customers have potentials to postpone or even not to redeem their pawned gold. These phenomena may result in losses experienced by Syariah banks.

Gold pawn practice has to be restudied to avoid speculative possibilities. On one hand, Syariah banking practitioners should accommodate the financial market demands that syariah banks may compete with the other conventional banks, both in fund raising products, distributions, and services required by the society. On the other hand, Syariah compliance should be realized that the practices of syariah banks will never be the same with those of conventional banks.

Due to the new innovations of Syariah banks' product development, the National Syariah Council of the Indonesian Ulema Council (DSN MUI) has issued approximately more than 80 fatwa (rules) related to Syariah banks' products. According to [3], the legitimacy of DSN MUI is acknowledged by the regulations of law to formulate syariah principles on Syariah economic and financial sectors. It is shown on the Decision Letter of the Director of Bank Indonesia number 32/34/1999 article 31 stating that: "To perform business activities, the common Syariah Banks are obliged to pay better attention on DSN MUI fatwa". In this case, all products made by Syariah banks should be based on DSN MUI fatwa for its legal bases of the products.

Gold pawning practices are accommodated by the Fatwa Board Number 26/DSN-MUI/ III/2002. The reasons why gold pawning is allowed is based on sura al-Baqarah: 283 stating that "If you are in the middle of a journey (and you make a non-cash mu'amalah), and you cannot find a note taker, there must be something used as insurance held (by the indebted)". In addition, The Prophet's hadith narrated by al-Bukhari and Muslim derived from A'isyah r.a where the Prophet Muhammad once pawned his iron clothes to a Jewish in Madinah. Similarly, to the Prophet's hadith narrated by al-Syafi'i, al-Daraquthni and Ibnu Majah derived from Abu Hurairah stating that "the possession on something pawned may not be separated from the pawning owner". He may gain the benefits but should also take the risks.

The above mentioned DSN MUI fatwa strengthens the gold rahn bases mentioned in the Prophet's hadith narrated by Jama'ah, unless Muslim, al-Nasa'i, and The Prophet state that: the pawned vehicles may be ridden by bearing the cost and the pawned livestocks may be taken their milk by bearing the cost as well. Anyone who rides on the vehicle and takes the livestocks' milk is obliged to provide care dan maintenance costs. The above Fatwa also quoted ulema's ijma (agreement among ulema) which allows rahn agreement as cited from [4] stating that "basically any muamalat form may be made unless there is a disallowing rule".

Gold pawning is allowed to make due to the applicable current habit. It is shown on a hadith quoted by the ulemas that the pawn made is not in the form of gold but the other commodities. However, this community habit is susceptible to the speculative actions. The applicable conditions mentioned in hadith stating that gold exchange may result in riba fadhl and prohibition on non- formidable gold purchase and sale considered to determine gold pawning as a speculative object.

stress testing is conducted based on the followings procedures: determine the initial gold value, calculate the initial amount of gold, calculate the amount of the second gold, calculate the Qardh value of the second gold, calculate the amount of the third gold, calculate the total value of gold, calculate the difference between the initial and the last gold value, execute the first gold in a lag for 1 month, execute the second gold in a lag for 2 months, execute the third gold in a lag for 3 months, calculate the gold farming loan settlement, calculate the gold farming Net Profit and analyze the gold farming Stress Testing results whether the gold farming practices are profitable both for the bank and customers.

\section{METHODOLOGY}

A research based on stress testing method is conducted with the gold farming simulation on gold pawning practices in Indonesian banking. The secondary data are used in this research, that is, the cumulative gold pawning value (qardh) in Indonesian syariah banking starting from March 2014 to May 2015. In addition, the secondary data used are IDR in USD exchange rate, gold price/ounce/USD, main capital (tier 1), supplementary capital (tier2), continuous yearly profits, Risk Weighted Asset (ATMR) and Capital Adequacy Ratio starting from March 2004 to May 2015.

The stress testing process is initiated by conducting a simulation. According to [5] simulation is an activity imitating operations and attitudes from various real situation, both facilities and processes. The real situation may be simulated is called a system in which requires various assumptions to learn about it. Nasution also states that simulation is a method to generate conditions of situational models to study, examine or try and 
others. The other definition taken and started that simulation is an imitation of the existing operational processes in the real world or system at a certain time. Simulation is also a set of methods and applications used to imitate behavior of a system which is sometimes used by utilizing a computer equipped with appropriate software.Simulation is an experimental approach. The limited analytical method to overcome the complex dynamic system which enables simulation functioning as the best alternative conducted both manually or by utilizing computer which involves observation and generalization of artificial history of a system to explain the conclusions of the real operational characteristics. Simulation is one method type to learn about a system. Various system types may be in the forms of mathematical equations or logical relations which generate a model required to learn as the system works.

According to [6] that a stress testing method is a test used to examine whether a bank keeps maintaining itself with the unstable economic/financial condition or not. Stress testing, specifically provides information on how much capital is required to avoid default condition due to the major loss. In this case, the impacts of gold price decrease on Syariah banks' Capital Adequacy Ratio (CAR) are required to be examined.

Stress testing may be formulated on a simple or complex scenario to measure the impact of one or more risks towards a bank or industry. Therefore, [7] releases 21 principles to introduce stress testing on practices and supervisions. One of the statements is as follows:

"a bank should operate a stress testing program that: promotes risk identification and control; provides a complementary risk perspective to other risk management tools; improves capital and liquidity management; and enhance internal and external communication. The above statement emphasizes on bank to operate stress testing program to identify and control risks, improve capital and liquidity management as well as enhance internal and external communication.

According to [7], the functions of stress testing are as follows:

a) To present risk assessments in the future

b) To overcome limitations on models and historical data

c) To support internal and external communication

d) To generate capital and liquidity planning procedures

e) To inform bank risk tolerance establishment

f) To facilitate risk mitigation or plan development which may pass the depressed conditional coverage.

As explanation by [8] that a stress testing method is used to detect extreme events which may create major losses. Although extreme events have small probability, the impact may be very serious to the organization.

To conduct stress testing on gold farming simulation, the author uses the following formulation: First stage, the initial qardh data value of gold pawning is processed using the following formulation:

$\mathrm{Q}_{\mathrm{t}}=\left(\mathrm{M}_{\mathrm{t}}\right) /\left(\mathrm{L}_{\mathrm{t}}\right)$

Model (1) explains that to obtain the initial qardh value $\left(\mathrm{Q}_{\mathrm{t}}\right)$ the gold value $\left(\mathrm{M}_{\mathrm{t}}\right)$ after being pawned in the first month is divided with the gold estimated value $\left(\mathrm{L}_{\mathrm{t}}\right)$ which is determined by syariah bank. In this simulation, Loan to Value (LTV) of $75 \%$ is divided with the initial qardh value. To find the gold value in the forms of currency nominal value in model (1) then model (2) is used as follows:

$\mathrm{M}_{\mathrm{t}}=\left(\mathrm{X}_{\mathrm{t}}\right)\left(\mathrm{P}_{\mathrm{t}}\right)$

Model (2) explains how to obtain the gold value that the total gold weight $\left(\mathrm{X}_{\mathrm{t}}\right)$ is multiplied with the gold price $\left(\mathrm{P}_{\mathrm{t}}\right)$ in the specified transaction month.

To obtain the gold price $\left(\mathrm{P}_{\mathrm{t}}\right)$, the formula is as follows:

$\mathrm{P}_{\mathrm{t}}=\left(\mathrm{K}_{\mathrm{t}}\right)\left(\mathrm{P}_{\mathrm{mt}}\right)$

Model (3) explains how to obtain the price level that the exchange rate value $\left(\mathrm{K}_{\mathrm{t}}\right)$ is then multiplied with the gold market price $\left(\mathrm{P}_{\mathrm{mt}}\right)$.

To obtain the gold weight, the following equation is used as follows:

Ounce $=\frac{M_{t}}{K_{t} P_{t}}$.

Equation (4) explains how to obtain the total gold weight purchased at a price and exchange rate of that month that the gold price is divided with the dollar exchange rate and multiplied with the gold price.

To use Qardh in purchasing the second gold, a customer has obtained a certain amount of money from the first gold spawning. If he wishes to pawn his gold once again, the formula may be used as follows:

$\mathrm{X}_{\mathrm{t}+1}=\frac{Q_{\mathrm{t}}}{\left(K_{\mathrm{t}+1}\right)\left(P_{m+1}\right)}$. 
Model (5) explains that the amount of gold which may be purchased should be in accordance with the amount of money obtained from the first gold pawning $(\mathrm{Qt})$ compared with the value of Dollar exchange rate $\left(\mathrm{K}_{\mathrm{t}+1}\right)$ in the following month and the price of gold $\left(P_{m+1}\right)$ in the following month with the conditions as follows:

Explanation:

$$
\left[\begin{array}{c}
\text { if }\left(k_{t+1}\right)\left(P_{m t+1}\right)<\left(K_{t}\right)\left(P_{m t}\right) \rightarrow X_{t+1} \\
\text { dan } \\
\text { if }\left(k_{t+1}\right)\left(P_{m t+1}\right)>\left(K_{t}\right)\left(P_{m t}\right) \rightarrow Q_{t}
\end{array}\right]
$$

The decision to purchase the second gold depends on the price of Dollar exchange rate $\left(k u r s_{t+1}\right)$ in the following month and the gold price in the following month $\left(\mathrm{P}_{\mathrm{mt+1}}\right)$. If the Dollar exchange rate $\left(\right.$ kurs $\left._{t+1}\right)$ in the following month and the gold price in the following month $\left(\mathrm{P}_{\mathrm{mt+1}}\right)$ are lower than the Dollar exchange rate in the specified transaction month $\left(\right.$ kur $\left._{t}\right)$ and the gold price in the specified transaction month $\left(\mathrm{P}_{\mathrm{mt}}\right)$ that the gold purchasing decision can be made.

However, if the Dollar exchange rate $\left(\right.$ kurs $\left._{t+1}\right)$ in the following month and the price of gold in the following month $\left(\mathrm{P}_{\mathrm{mt}+1}\right)$ is more than the Dollar exchange rate in the speciefied transaction month $\left(\right.$ kur $\left.s_{t}\right)$ and the gold price in the specified transaction month (Pmt), the gold purchasing decision cannot be made (keeping the gold in the form of qardh). formula:

By pawning the gold (qardh) for the second time to obtain the second qardh we use the following

$$
\begin{aligned}
& Q_{t+2}=\left(M_{t+2}\right)\left(K_{t+2}\right)\left(P_{m t+2}\right)\left(L_{t+2}\right) \\
& \left.=X_{t+1}\right)\left(P_{m t+1}\right)\left(K_{t+2}\right)\left(P_{m t+2}\right)\left(L_{t+2}\right) \ldots(6)
\end{aligned}
$$

We can say that in equation (6), by pawning the possessing gold, we may obtain the gold that we have pawned before and so forth. To purchase the third gold, we can use the following formula:

$$
\mathrm{X}_{\mathrm{t}+3}=\frac{Q_{\mathrm{t}+\mathrm{z}}}{\left(K_{\mathrm{t}+\mathrm{g}}\right)\left(p_{\mathrm{mt}+\mathrm{g}}\right)}
$$

$$
\begin{aligned}
& \text { Conditions: } \\
& \text { if }\left(k_{t+3}\right)\left(P_{m t+3}\right)<\text { if }\left(k_{t+2}\right)\left(P_{m t+2}\right) \rightarrow \mathrm{X}_{t+2} \\
& \text { if }\left(k_{t+3}\right)\left(P_{m t+3}\right)>\left(k_{t+2}\right)\left(P_{m t+2}\right) \rightarrow \mathrm{X}_{t+2}
\end{aligned}
$$

Explanation:

Equation (7) explains that the decision to purchase the second gold depends on the price of Dollar exchange rate $\left(\right.$ kurs $\left._{t+3}\right)$ in the following month and the price of gold in the following month $\left(\mathrm{P}_{\mathrm{mt}+3}\right)$. If the Dollar exchange rate $\left(\right.$ kurs $\left._{t+3}\right)$ in the following month and the price of gold in the following month $\left(\mathrm{P}_{\mathrm{mt}+3}\right)$ are lower than the Dollar exchange rate in the specified transaction month $\left(\right.$ kur $\left._{t}\right)$ and the gold price in the specified transaction month $\left(\mathrm{P}_{\mathrm{mt}}\right)$, the gold purchasing decision can be made.

However, if the Dollar exchange rate $\left(\right.$ kurs $\left._{t+3}\right)$ in the following month and the gold price in the following month $\left(\mathrm{P}_{\mathrm{mt}+3}\right)$ is more than the exchange rate of Dollar in the specified transaction month $\left(\right.$ kur $\left._{t+2}\right)$ and the gold price in the specified transaction month $\left(\mathrm{P}_{\mathrm{mt}+2}\right)$, the gold purchasing decision cannot be made (keeping the gold in the form of qardh).

To examine the gold pawning in the form of gold farming, stress testing simulation may be conducted by continuing the above business simulation model through the following steps:

First, sell the first gold up to the third one.

The first gold may be sold due to the following conditions:

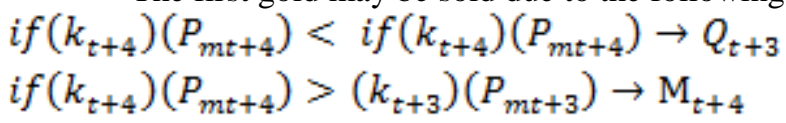

The first gold which has been pawned may be sold when the gold price in the specified transaction month is higher than the gold price in the market in the previous month.

The second gold may be sold due the following conditions:

if $\left(k_{t+4}\right)\left(P_{m t+4}\right)<i\left(k_{t+3}\right)\left(P_{m t+3}\right) \rightarrow Q_{t+2}$ 


\section{if $\left(k_{t+4}\right)\left(P_{m t+4}\right)>\left(k_{t+3}\right)\left(P_{m t+3}\right) \rightarrow \mathrm{M}_{t+4}$}

The second gold which has been pawned may be sold when the gold price in the specified transaction month is higher than the gold price in the market in the previous month.

The third gold may be sold due the following conditions:

$$
\begin{aligned}
& \text { if }\left(k_{t+4}\right)\left(P_{m t+4}\right)<\left(k_{t+3}\right)\left(P_{m t+3}\right) \rightarrow Q_{t+3} \\
& \text { if }\left(k_{t+4}\right)\left(P_{m t+4}\right)>\left(k_{t+3}\right)\left(P_{m t+3}\right) \rightarrow \mathrm{M}_{t+4}
\end{aligned}
$$

The third gold which has been pawned may be sold when the gold price in the specified transaction month is higher than the gold price in the market in the previous month.

Second, completely pay the debts

The total value of gold owned is the total amount sale of the first gold plus that of the 2 nd one and that of $3 \mathrm{rd}$ one or $M_{t+4} \times 3$. The Total Debt is the qardh to buy a second gold plus the qardh of the $2^{\text {nd }}$ one plus the qardh of the $2^{\text {nd }}$ one to buy the 3 rd one or $Q_{t+1}+Q_{t+2}$ that the total amount complete payment is:

$M_{\text {net }}=\left(3 M_{t+4}\right) \rightarrow Q_{t+1}+Q_{t+2}$

Third, calculate the Gold Farming Profits and Losses

Profit is the gold Net value subtracted with the initial investment of the gold value due to the following formula:

$$
\left\lceil\begin{array}{c}
M_{\text {net }}-M_{t}=\text { Positif } \\
M_{\text {net }}-M_{t}=\text { Negatif }
\end{array} \mid\right.
$$

If the remaining debt payment subtracted with the initial capital has positive value, then the gold farming investment value results in profits. However, if the remaining debt payment subtracted with the initial capital has negative value, then the gold farming results in losses.

\section{RESULT AND DISCUSSION}

The gold qardh data collected since March 2004 - May 2015 show the initial gold value, that is, the gold qardh value divided by $75 \%$ due to the equation (1). The value of $75 \%$ is the Loan to Value (LTV), in which this value is Bank estimation on the gold qardh value. In March 2004, for example, the gold qardh value is IDR 5.8 billion. The value already includes LTV value. However, each Bank has different LTV value. In these data, the LTV value is assumed by $75 \%$. Thus, the value of IDR 5.8 billion divided by $75 \%$ equals to IDR 7.74 billion. It is the total value before estimated by the bank or a market value without LTV. In April 2004, the gold qardh value is IDR 5.73 billion while in May 2015 the gold qardh value is IDR 662.3 billion. The lowest gold qardh value is in October 2004 by IDR 780 million and the highest gold qardh value is in September 2011 by IDR 3.6 trillion.

The first gold total amount in this simulation is a calculation of the gold amount which may be purchased with the gold qardh value due to the equation (2). The obtained data explain that in March 2004, the first gold amount which may be purchased with IDR 7.74 billion is 2,642 ounces, resulted from the calculation of the total initial qardh of IDR 7.74 billion divided by gold price per USD per ounce of USD 341 multiplied with IDR rate of IDR 8,587 in March 2004 that the gold amount may be purchased is 2,642 ounces. Similarly, in April 2004, the gold amount which may be purchased is 2.854 ounces while in March 2015 the gold amount may be purchased is 56,434 ounces. The lowest gold amount over a period of 135 months since March 2004 to May 2015 is 334 ounces in October 2004 whiel the highest gold amount is in September 2011 by 343,001 ounces.

The decision to buy the second gold depends on the USD rate price and the gold price in the following month due to the equation (5). If the USD rate and the gold price in the following month is lower than those in the specified transaction month, then the decision to buy gold is feasible. However, if the USD rate and the gold price in the following month is higher than those in the specified transaction month, the decision to buy gold is not feasible (keeping the gold in the form of qardh). Based on the above data, the second gold amount is obtained from the money generated from the first gold qardh of IDR 5.8 billion in March 2004. The second gold maybe obtained with conditions that if the gold price in April 2004 is lower than that in March 2004, then the second gold may be purchased with the money obtained from the first gold. As exemplified in April 2004, the gold price in April 2004 is IDR 2,679,713 which is less than that in March 2004 of IDR 2,929.54. Thus the gold amount may be purchased as the first gold is 2,642 ounces. However, if the gold price in May 2004, for 
example, is IDR 2,914,412 higher than that in the previous month, for example, April 2004 which is IDR 2,679,713, then the gold amount may be purchased is 1,968 ounces with the price in May 2004.

The second gold qardh nominal value may be calculated with both IDR and USD rates in the specified transaction month as stated in the equation (5). If the gold is purchased by 2,642 ounces in April 2004 and was then pawned once again, then the amount of money we may obtain is IDR 5.3 billion. The value is calculated based on the gold price per USD multiplied with USD rate in the specified transaction month. The amount is then multiplied with LTV of 75\% due to the provisions of Syariah banks that the gold qardh value is obtained. The data analytical results show that the gold value obtained in April 2004 is IDR 5.3 billion, that in May 2004 is IDR 4.3 billion, and that in May 2015 is IDR 529 billion. Meanwhile, the lowest value of the second gold pawning is IDR 585 million in November 2004 and the highest is in October 2011 by IDR 2.7 trillion.

The third gold value is obtained by repurchasing the gold with a total amount of IDR 5.3 billion that, the gold amount may be purchased is 1,788 ounces adjusted with the gold price in the following month. It is shown from the obtained data in May 2004, when the gold price in June is IDR. 2,969,491 (the multiplication of gold price per USD 315 multiplied with rupiah rate of IDR. 9,415) which is higher than that in May 2004 by IDR 2,914,412 (the multiplication of gold price per USD 316 multiplied with rupiah rate of IDR. 9,210) that the gold amount may be purchased is 1,788 ounces. The subsequent developments show that in June 2004, the gold amount may be purchased with rupiah value and USD rate in the the specified transaction month is 1,449 ounces. In May 2015, the gold amount may be purchased is 48,056 ounces. The lowest gold amount of gold over a period of 132 months from May 2004 to May 2015 is 180 ounces in December 2004 and the highest one is in November 2011 by 172,625 ounces.

In addition, the total value of gold is the total amount of the third gold price retained waiting for the gold price increase. In May 2004, the total value of customers' gold is IDR.17 billion which is resulted by adding the first gold price of IDR. 6.2 billion (May 2004) plus that of second one of IDR. 5.7 billion (Multiplication of gold price per USD multiplied with USD rate, then multiplied with the second gold amount of 1,968 ounces) and then added with the third gold amount of IDR. 5.2 billion (Multiplication of gold price per USD 316 multiplied with rupiah rate of IDR. 9,210 multiplied with the gold amount of 1,788 ounces). In the following month of June 2004, the total value of gold is IDR. 11 billion and last month in May 2005, the gold amount is IDR 2.3 trillion. The lowest gold value is in November 2014 by IDR 3.2 billion while the highest one is by IDR 8.897 trillion in September 2011.

The total amount of gold is obtained with the amount addition of the first, the second and the third gold. Based on the simulation results, the total amount of the first gold in May 2004 is 2,135 ounces, the second one is 1,968 ounces, and the third one is 1,788 ounces. It means that the total those three is 5,892 ounces. The total gold amount in June 2004 is 3,711 ounces, while that in May 2015 is 149620 . Thus, the lowest gold amount is 988 ounces in November 2004 and the highest one is in September 2011 by 620,955 ounces.

The simulation result of difference between initial and end gold value is shown in equation (8) which describes the costumers' initial value in using the initial capital in gold pawning to purchase the second and the third one. After those three golds are collected, then gold price are measured in the specified transaction month subtracted with the initial capital when pawning the gold at the first time. The difference of gold value between the initial and the end gold value is IDR 10.9 billion, that is, the substraction of the total gold value of IDR17.17 billion subtracted with the initial gold value of IDR 6,2 billion, and this is shown in data of May 2004. However, in June 2004, the difference of value is IDR. 8.9 billion. The lowest value is IDR 1.5 billion in November 2004 while the highest one is IDR 1.5 trillion in October 2011.

The first gold execution in 1-month lag can be made if gold price per ounce per USD multiplied with rupiah rate per USD in the following month is higher than that in the specified transaction month. Conversely, if the gold price per ounce per USD multiplied with rupiah rate per USD in the following month is less than that in the specified transaction month, the gold may be retained. In June 2004, for example, when compared between the gold price per ounce per USD multiplied with USD rate that the gold price is equal to IDR. 2,969,491, it is higher than that in May 2004 which is IDR. 2,914,412. Thus, the gold execution is made to obtain the gold sale value of IDR. 6.3 billion In July 2004. The gold value of IDR 2,868,117 is lower than that of in June with IDR $2,969,491$ that the gold is retained in the form qardh of IDR 1.536 billion as the value of qardh in early June is IDR. 1.536 billion. It is similarly made in the next few months. In January 2011, the gold is retained as the gold price in January 2011 is IDR. 9,656,936 which is lower that that in December 2010 with IDR 10,219,386. In May 2015, the gold price is at IDR 15,649,780 which is higher that that in April 2015 with IDR 15,245,211 that the gold is sold at a price of IDR 966 billion.

Similarly, the second gold execution in 2-month lag 2 can be made if the gold price per ounce per USD multiplied with USD rate in the following month is higher than that in the specified transaction month. Conversely, if the gold price per ounce per USD multiplied with USD rate in the following month is less than that in the specified transaction month, the gold may be retained. Based on above simulation results, in June 2004, for example, when the gold price per ounce per USD multiplied with the rupiah rate, the gold price of IDR 
2,969,491 is higher than that in May 2004 of IDR2,914,412 that the execution is made. Thus, the amount of money may be obtained from the gold sale is IDR 5.84 billion. However, in July 2004, the gold value of IDR $2,868,117$ is lower that that in June 2004 of IDR 2,969,491. Thus, the second gold may be retained in the form qardh of IDR. 3.5 billion, as it is similar with that in June 2004 .

The third gold xxecution in 3-month lag can made if the gold price per ounce per USD multiplied with rupiah rate per USD in the following month is higher than that in the specified transaction month. Conversely, if the gold price per ounce per USD multiplied with rupiah rate per USD in the following month is less than that in the specified transaction month, the gold may be retained. The simulation results in June 2004 show that the gold price per ounce per USD multiplied with the rupiah rate per USD, the gold price of IDR 2,969,491 is higher than that in May 2004 with IDR 2,914,412. Thus, the gold execution is made to obtain the gold sale value of IDR. 5.3 billion. However, in April 2005, the gold value of IDR 3,325,690 is higher than that in March 2005 of IDR 3,248,606. Thus, the third gold would be sold at the amount of IDR 4.1 billion.

Gold farming debt complete payment should be made by the result addition covering the first, the second and the third gold sale within 1-month lag in the above subtracted with the initial capital for purchasing the first and the second gold. Thus, the gold farming debts may be completely paid.

The gold farming debt payment scenario is adjusted with the gold prices in the specified transaction month. The results of gold farming debt payment simulation in early June 2004 are conducted by sales addition of the first, the second and the third gold in 1-month lag in the specified transaction month with IDR 17.4 billion subtracted with the initial capital from the first and second gold purchases of IDR 5.03 billion. Thus, the gold farming debt complete payment is IDR 12.45 billion in June 2004. Meanwhile, the complete debt payment in July 2004 is IDR 3.2 billion that the debt repayment is negative in December 2004 with IDR $-584,582,400,-$, in January 2005 with IDR -3.84 billion, in August 2005 with IDR -537,210,757, in February 2006 with IDR978,498,529, in August 2006 with IDR -2.02 billion, in March 2007 with IDR -9.6 billion, in March 2008 with IDR -3.9 billion, January 2011 of IDR -117 billion and September 2011 with IDR -1.7 trillion.

The gold farming net is the simulation result of customers' gold farming activities. The objective is to figure out whether gold farming is profitable or even resulting in losses. The above statement may be illustrated in the following Figure 1.

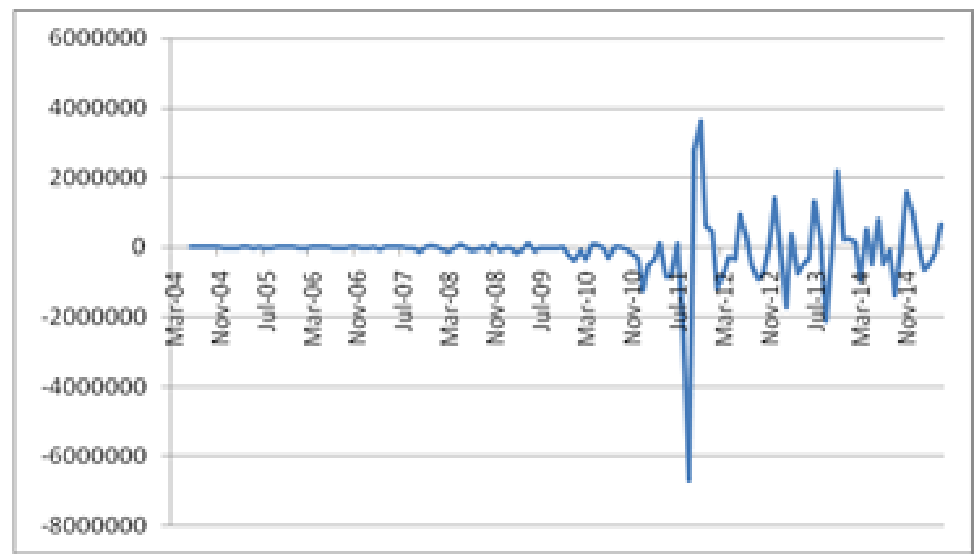

Figure 1. Gold Farming Net Profits of March 2004 - May 2015

The simulation results upon the analyzed data starting from March 2004 to May 2015 show that after gold farming debt payment, the customer may obtain the remaining amount of gold farming debt payment of June 2004 with IDR 12 billion subtracted with customers' initial amount of money with IDR 2.04 billion. Then the remaining money of IDR 10.4 billion is the customers' profits obtained from gold farming in June 2004. However, not all within a period of 131 months from March 2004 to May 2015, the costumers continuously generate profits. The profits are only obtained within 48 months while the losses are within 83 months.

In June 2004, the customers obtain profits of IDR. 10.4 billion. However, in July and August 2004, they experience losses respectively with IDR. -2.7 billion and IDR -2.29 billion. In April 2014, there are also losses with IDR -128 billion and at the end of May 2015, there are profits obtained from gold farming with IDR 676 billion.

The stress testing results on gold farming simulation from March 2004 to May 2015 show that costumers' profits are obtained in the following Table 1: 
Table 1. Stress Testing Result Findings on Customes'r Profits

\begin{tabular}{|r|r|r|r|r|r|r|r|r|}
\hline No. & \multicolumn{1}{l|}{ Bulan } & \multicolumn{1}{c|}{ Net profit } & \multicolumn{1}{l|}{ No. } & \multicolumn{1}{l}{ Bulan } & \multicolumn{1}{c|}{ Net profit } & No. & Bulan & \multicolumn{1}{c|}{ Net profit } \\
\hline 1 & Jun-04 & $10,408,225,264$ & 19 & Jun-08 & $27,713,361,886$ & 37 & Dec-12 & $1,447,057,146,951$ \\
\hline 2 & Sep-04 & $6,349,294,279$ & 20 & Sep-08 & $24,560,591,475$ & 38 & Mar-13 & $406,571,692,555$ \\
\hline 3 & Oct-04 & $7,025,546,293$ & 21 & Nov-08 & $73,463,228,325$ & 39 & Jul-13 & $1,329,348,210,037$ \\
\hline 4 & Nov-04 & $2,273,027,759$ & 22 & May-09 & $112,145,861,495$ & 40 & Aug-13 & $145,264,098,226$ \\
\hline 5 & Jun-05 & $7,643,111,213$ & 23 & Nov-09 & $12,328,607,683$ & 41 & Oct-13 & $9,222,852,232$ \\
\hline 6 & Sep-05 & $10,962,307,645$ & 24 & Apr-10 & $89,077,307,007$ & 42 & Nov-13 & $2,201,033,731,737$ \\
\hline 7 & Oct-05 & $6,973,987,424$ & 25 & May-10 & $89,482,356,302$ & 43 & Dec-13 & $230,461,746,312$ \\
\hline 8 & Nov-05 & $9,144,294,231$ & 26 & Aug-10 & $27,001,984,353$ & 44 & Jan-14 & $262,291,721,858$ \\
\hline 9 & Apr-06 & $2,114,466,291$ & 27 & Sep-10 & $27,049,433,981$ & 45 & Feb-14 & $140,820,480,708$ \\
\hline 10 & Jun-06 & $4,994,727,104$ & 28 & Apr-11 & $110,270,724,436$ & 46 & Apr-14 & $530,249,222,147$ \\
\hline 11 & Oct-06 & $2,387,600,897$ & 29 & Jul-11 & $134,858,764,883$ & 47 & Jun-14 & $796,606,396,419$ \\
\hline 12 & Feb-07 & $2,487,697,026$ & 30 & Oct-11 $2,782,788,040,340$ & 48 & Oct-14 & $51,485,596,196$ \\
\hline 13 & May-07 & $2,072,512,410$ & 31 & Nov-11 & $3,620,561,487,601$ & 49 & Nov-14 & $1,600,918,275,230$ \\
\hline 14 & Jun-07 & $6,446,233,698$ & 32 & Dec-11 & $625,316,087,622$ & 50 & Dec-14 & $999,360,176,120$ \\
\hline 15 & Nov-07 & $11,212,796,632$ & 33 & Jan-12 & $455,898,033,852$ & 51 & Jan-15 & $149,708,541,488$ \\
\hline 16 & Dec-07 & $60,138,665,341$ & 34 & Jun-12 & $953,406,996,987$ & 52 & May-15 & $676,535,311,542$ \\
\hline 17 & Jan-08 & $6,234,289,029$ & 35 & Jul-12 & $281,851,712,581$ & & & \\
\hline 18 & May-08 & $71,720,067,799$ & 36 & Nov-12 & $134,885,336,819$ & & & \\
\end{tabular}

The table above explains that customers obtained profits from gold farming acivities. However, the customers also experience losses. At the beginning of this research, for example in June 2004, the remaining debt repayment result is IDR. 12 billion subtracted with customer's initial capital of IDR 2.04 billion. Thus, the remaining amount of customers' profit while having gold farming activities is IDR 10.4 billion.

At the end of this research, in May 2015, the customers obtained profits of IDR. 676.5 billion. The lowest profit in May 2007 is IDR 2.07 billion while the highest is IDR 3.6 trillion.

However, not all within a period of 131 months from March 2004 to May 2015 the costumers continuously generate profits as illustrated in the following Table 2:

Table 2. Stress Testing Result Findings on Customers' Losses while having gold farming activities

\begin{tabular}{|c|c|c|c|c|c|c|c|c|}
\hline No. & Bulan & Net profit & No. & Bulan & Net profit & No. & Bulan & Net profit \\
\hline 1 & Jul-04 & $-2,799,593,378$ & 28 & Feb-08 & $-69,606,407,421$ & 55 & Mar-11 & $-337,617,232,176$ \\
\hline 2 & Aug-04 & $-2,298,965,645$ & 29 & Mar-08 & $-124,511,071,908$ & 56 & May-11 & $-870,575,085,120$ \\
\hline 3 & Dec-04 & $-4,427,649,067$ & 30 & Apr-08 & $-34,794,794,139$ & 57 & Jun-11 & $-812,826,248,080$ \\
\hline 4 & Jan-05 & $-11,169,479,331$ & 31 & Jul-08 & $-76,246,008,848$ & 58 & Aug-11 & $-2,124,844,278,642$ \\
\hline 5 & Feb-05 & $-4,887,986,621$ & 32 & Aug-08 & $-71,618,940,706$ & 59 & Sep-11 & $-6,680,251,774,870$ \\
\hline 6 & Mar-05 & $-2,356,199,752$ & 33 & Oct-08 & $-87,265,232,450$ & 60 & Feb-12 & $-1,153,858,540,588$ \\
\hline 7 & Apr-05 & $-994,263,743$ & 34 & Dec-08 & $-93,317,414,261$ & 61 & Mar-12 & $-758,373,542,381$ \\
\hline 8 & May-05 & $-4,338,219,097$ & 35 & Jan-09 & $-26,429,966,523$ & 62 & Apr-12 & $-252,099,594,331$ \\
\hline 9 & Jul-05 & $-4,522,054,210$ & 36 & Feb-09 & $-37,031,824,542$ & 63 & May-12 & $-341,113,077,535$ \\
\hline 10 & Aug-05 & $-19,865,957,424$ & 37 & Mar-09 & $-172,817,075,248$ & 64 & Aug-12 & $-517,529,229,804$ \\
\hline 11 & Dec-05 & $-2,762,973,342$ & 38 & Apr-09 & $-56,770,218,666$ & 65 & Sep-12 & $-909,343,862,455$ \\
\hline 12 & Jan-06 & $-7,402,610,818$ & 39 & Jun-09 & $-79,514,938,147$ & 66 & Oct-12 & $-738,557,749,937$ \\
\hline 13 & Feb-06 & $-12,632,898,529$ & 40 & Jul-09 & $-26,434,273,214$ & 67 & Jan-13 & $-261,414,027,997$ \\
\hline 14 & Mar-06 & $-2,702,069,710$ & 41 & Aug-09 & $-29,714,898,230$ & 68 & Feb-13 & $-1,736,395,127,134$ \\
\hline 15 & May-06 & $-1,270,503,014$ & 42 & Sep-09 & $-26,181,255,454$ & 69 & Apr-13 & $-760,250,508,154$ \\
\hline 16 & Jul-06 & $-3,935,731,789$ & 43 & Oct-09 & $-27,539,057,184$ & 70 & May-13 & $-509,721,366,300$ \\
\hline 17 & Aug-06 & $-18,903,276,904$ & 44 & Dec-09 & $-214,867,001,231$ & 71 & Jun-13 & $-282,986,807,940$ \\
\hline 18 & Sep-06 & $-18,027,942,055$ & 45 & Jan-10 & $-360,772,908,371$ & 72 & Sep-13 & $-2,090,306,889,291$ \\
\hline 19 & Nov-06 & $-1,431,141,675$ & 46 & Feb-10 & $-90,661,270,170$ & 73 & Mar-14 & $-966,008,318,628$ \\
\hline 20 & Dec-06 & $-13,022,583,733$ & 47 & Mar-10 & $-334,866,899,604$ & 74 & May-14 & $-463,010,055,577$ \\
\hline 21 & Jan-07 & $-24,415,741,420$ & 48 & Jun-10 & $-28,426,545,741$ & 75 & Jul-14 & $-470,052,841,194$ \\
\hline 22 & Mar-07 & $-59,204,497,581$ & 49 & Jul-10 & $-312,274,643,997$ & 76 & Aug-14 & $-92,790,801,894$ \\
\hline 23 & Apr-07 & $-2,091,809,672$ & 50 & Oct-10 & $-68,263,359,735$ & 77 & Sep-14 & $-1,358,464,783,643$ \\
\hline 24 & Jul-07 & $-1,195,937,340$ & 51 & Nov-10 & $-161,762,537,252$ & 78 & Feb-15 & $-641,923,035,176$ \\
\hline 25 & Aug-07 & $-14,465,699,995$ & 52 & Dec-10 & $-290,264,436,278$ & 79 & Mar-15 & $-484,663,312,837$ \\
\hline 26 & Sep-07 & $-7,977,394,595$ & 53 & Jan-11 & $-1,224,848,557,818$ & 80 & Apr-15 & $-128,496,224,441$ \\
\hline 27 & Oct-07 & $-115,136,759,399$ & 54 & Feb-11 & $-495,569,291,324$ & & & \\
\hline
\end{tabular}


Customer losses in gold farming take place in July and August 2004 with losses respectively by IDR 2.7 billion and IDR -2.29 billion. In April 2014, there are losses of IDR -128 billion and at the end of May 2015, the gold farming profit is IDR 676 billion. Based on the stress testing results within a period of 131 months from March 2004 to May 2015, the customers gain profits within 48 months while losses occur within 83 months.

When analyzed from the perspective of economy, the gold farming practices are made to borrow money for urgent necesities. However, when the gold price increase is used to obtain profitbe opportunities the tress testing based on the gold farming simulation shows that it may gain profits and losses at the same time. Within a period of 131 months, the customers mainly experienced losses. Profits and losses are affected by the rate exchange fluctuations of USD rate value against rupiah considering to the other factors as well. Thus, customers who pawn their gold intended to do gold farming, such action is considered as speculative or gharar actions. From the perspective of fiqh, gold pawning which tun to be gold farming is considered as hilah which is prohibited by syar'i. This is because the gold pawning intention is manipulated into gold farming. These gold farming practices are categorized into gambling and not in accordance with masalahah mursalah as there are speculations which are classified into maslahah sukuti or mulgha, that is, maslahah which is not justified by syara'.The maslahah which Syariah may achieve should be in general and universal. In general, it means that it is applicable not only to individuals, but also the entire human beings collectively. Universal means that maslahah should not only be applicable in certain period of time but also lasts forever along the time and human life.

\section{CONCLUSION}

The results of this research show that the gold pawning intended in fiqh is for tabarru agreement, not for business purposes (tijarah). Therefore, the agreement used is the qardh and not the tijarah one. Meanwhile, according to the Circular Letter No.14/7/DPbS - 29 February 2012 on special organization of the gold pawning qardh products for Syariah Bank and Syariah Business Units, that the gold pawning qardh may be combined with 'âwadhah agreement (exchange agreement and may be commercialized). This practice is not in accordance with the pawning concept intended in fiqh.

The results of gold farming simulation also show that both Bank and customers experience losses. In addition, the stress testing results show that gold pawning practices do not meet maslahah based on the gold pawning (rahn) practices. Thus, gold pawning management should be given to the pawning institutions (pawnshops). Otherwise, the gold pawning practices in banking sectors should be evaluated due to the allowed amount of gold pawning, of gold pawning tenor, of money disbursement and of gold farming frequency. The amount of gold pawning is equalized with the basic necessity consumption that speculative opportunities are not widely open. Similarly, tenor gold pawning should be limited and may not be extended although the amount is only slightly different. Money disbursement may not be made anytime, yet should be based on the specified date. To check the gold pawning frequency, Indonesian Bank is required to check the customers who have pawned (rahn) their gold in various Islamic banks and it should be limited with 1 (one) transaction only.

To improve the gold pawning management in the future, there are several suggestions and recommendations as follows:

a. focus group discussions should be made involving market actors, DSN MUI and experts in the field of Syariah banking, as well as regulators in order to examine the conformity of gold pawning practices as intended by DSN MUI fatwa No. 26/DSN-MUI/III/2002.

b. Econometric estimation is required to me made to figure out the conditions in the future whether gold pawning may turn into financial engineering or remain in the corridor of syariah.

c. Assessments are highly required by non-bank Syariah financial institutions which implement gold pawning (rahn) practices to see their conformity with syariah intended by DSN MUI fatwa No.26/ DSN-MUI/III/2002.

\section{REFERENCES}

[1] http://www.syariahmandiri.co.id/category/small-micro-business/gadai-emas-bsm

[2] Ismal, Rifki dan Musari, Khairunnisa (2012), Rentannya Gadai Emas di Bank Syariah, Bisnis Indonesia, 16 Juli

[3] Nafis, M. Cholil (2011), Teori Hukum Ekonomi Syariah: Kajian Komprehensif tentang Teori Hukum Ekonomi Islam, Penerapannya dalam Fatwa Dewan Syariah Nasional dan Penyerapannya ke dalam Peraturan Perundangundangan: Jakarta, UI-Press, h. 83

[4] az-Zuhaili, Wahbah (t.t), al-Fiqh al-Islamy Wa Adillatuhu: Beirut, Dar al-Fikr, juz V.

[5] Nasution, Arman Hakim dan Baihaqi, Imam (2007),Simulasi Bisnis: Yogyakarta, Penerbit ANDI,

[6] Ismal, Rifki (2011), Simulation-Based Stress Testing, dalam Islamic Banking in Indonesia: new perspective on monetary and financial issues, Published by John Wiley \& Sons Singapore Pte. Ltd.,.

[7] Bank for International Settlements (2009), Principles for Sound Stress Testing Practices and Supervision, Basel Committee on Banking Supervision, Switzerland

[8] Hanafi, Mamduh, M (2009), Manajemen Risiko, ed.II.:Yogyakarta, YKPN 